\title{
Light Symbolism in Gentile da Fabriano's Vatican Annunciation
}

\section{Simbolismo de la luz en la Anunciación de Gentile da Fabriano en la Pinacoteca Vaticana}

\author{
Lasse HODNE \\ Norwegian University of Science and Technology \\ lasse.hodne@ntnu.no
}

Recibido: $31 / 10 / 2014$

Aceptado: 10/11/2014

\begin{abstract}
Gentile da Fabriano's Annunciation in the Vatican Pinacoteca is one of the clearest and most interesting visualizations of a famous metaphor from Medieval hymn literature that compares Mary's hymen to the glass of a window. The painting uniquely combines three elements: rays of light, a Gothic tracery window, and the shape of the window impressed on the Virgin's body. Gentile's painting is the culmination of a development in Tuscan art that can be traced back at least until about 1370. This makes it part of an Italian tradition of visualizing the so-called $u t$ vitrum metaphor that must antedate analogous examples from Flemish art.
\end{abstract}

Key words: Gentile da Fabriano, Annunciation, ut vitrum, iconography.

Resumen: La Anunciación de Gentile da Fabriano en la Pinacoteca Vaticana es una de las visualizaciones más claras e interesantes de una famosa metáfora extraída de la literatura hímnica medieval que compara el himen de María al cristal de una ventana. La pintura combina de forma única tres elementos: los rayos de luz, una ventana de tracería gótica, y la forma de la ventana impresa en el cuerpo de la Virgen. La pintura de Gentile es la culminación de un desarrollo en el arte toscano que se remonta al menos hasta aproximadamente 1370. Esto la convierte en parte de una tradición italiana consistente en visualizar la llamada metáfora ut vitrum, la cual debe anteceder ejemplos análogos en el arte flamenco.

Palabras clave: Gentile da Fabriano, Anunciación, ut vitrum, iconografía.

$$
* * *
$$

In the Vatican Picture Gallery there is a small panel by Gentile da Fabriano, one of the most renowned exponents of International Gothic style (Fig. 1). ${ }^{1}$ The panel was probably made between 1420 and 1425, when the painter lived in Florence. ${ }^{2}$ It represents the Annunciation and shows the Virgin in a small room being approached by the angel. The only glimpse of the outside is a small portion on the left; just enough to let us have a glimpse of God the Almighty in the midst of a host of angels. From God issues a beam of light that, as it enters Mary's house, passes through a Gothic polylobed tracery window. The rays of light, which go in a straight line between God and the Virgin, create a replica of the shape of the window on the Virgin's body, just below her breasts (Fig. 2).

\footnotetext{
${ }^{1}$ By most critics, with the notable exception of Keith Christiansen, accepted as a genuine work by Gentile da Fabriano. Keith Christiansen, Gentile da Fabriano, Ithaca, Cornell University Press, 1982, p. 131. See also Andrea de MARCHI, Gentile da Fabriano. Un viaggio nella pittura italiana alla fine del gotico, Milan, Motta editore, 1992, p. 172.
}

${ }^{2}$ Christiansen, Op. cit., p. 4. 
An almost exact copy of this painting, probably executed by Gentile himself, was, until recently, part of the Barbara Piasecka Johnson collection. ${ }^{3}$

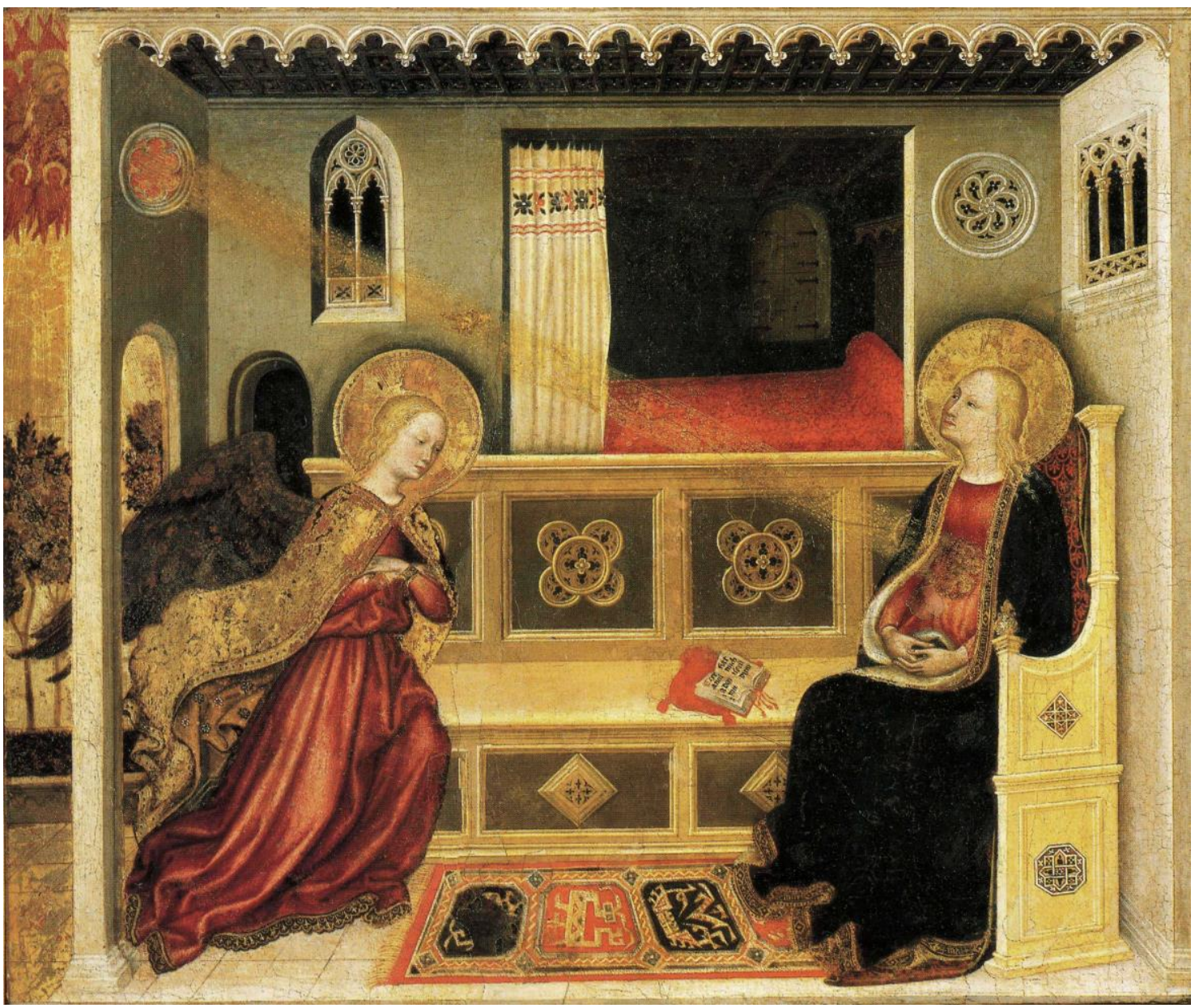

Fig. 1. Gentile da Fabriano, Annunciation, Pinacoteca Vaticana.

As far as I can see, the combination of three elements -the rays of light, the window, and the shape of the window impressed on the Virgin's body- is unique to Gentile da Fabriano. He thus expresses, more clearly than any other artist, what I will call the ut vitrum metaphor. In the present article I will attempt to explain the meaning of this metaphor, and give a broad outline of its origin and development in European Late Medieval and Renaissance art.

The Annunciation, arguably the most interesting Marian motif, represents a central Christian dogma, the Incarnation. This is the moment when Mary conceives; yet, despite the presence of the matrimonial bed in the background of some Annunciation scenes, there is very little that alludes to the intimacy of what is going on in this precise moment. Presenting the conception and pregnancy of Mary as quite different from that of other women, it confirms the idea that the Mother of God was Ever Virgin. But how was it possible for Mary to conceive without losing her virginity? How could she, to be blunt, become pregnant without losing the intactness of her

\footnotetext{
${ }^{3}$ As far as I know, works from this collection were sold on auction in 2014. I have no knowledge of this painting's present state or whereabouts.
} 
hymen? The hymen normally ruptures during intercourse, but in Mary's case, as the Apocrypha confirm, it remained intact. ${ }^{4}$

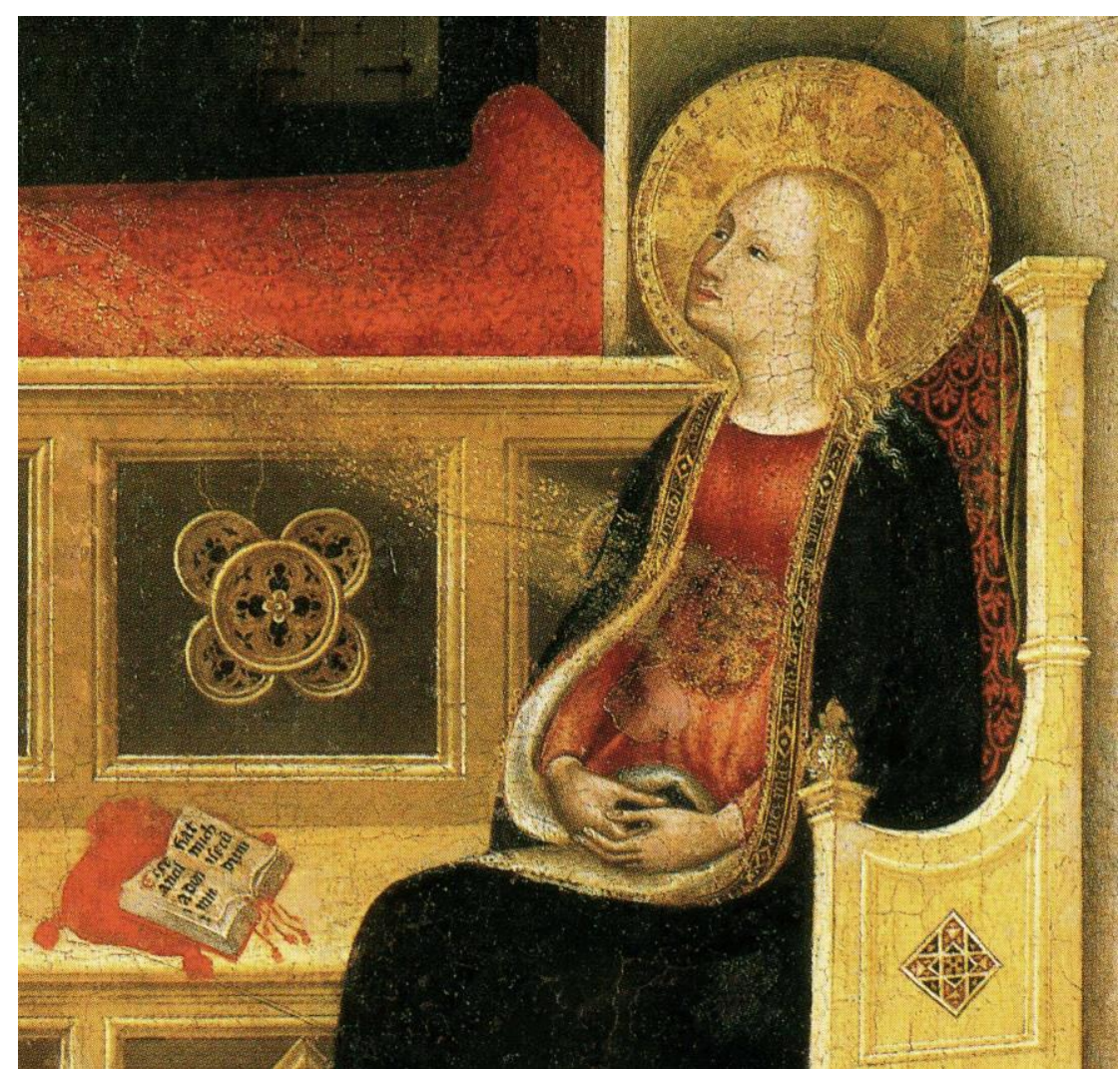

Fig. 2. Gentile da Fabriano, Annunciation, Pinacoteca Vaticana (detail).

One might perhaps think it inappropriate to ask questions concerning Mary's abdomen and the state of her hymen, but in patristic and scholastic theology such speculations were not at all unseemly. For them, it was important to know exactly how Mary could conceive and give birth without causing any damage to her virginity. Through this discussion, the possibility of Mary having been impregnated through an alternative orifice emerged. Thus, Proclus pronounced: "When the saintly Virgin gave her breast, the Word entered through the ear and the Holy Ghost gave life to the Temple." 5 The theory that Mary conceived through her ear was accepted and promulgated by the learned, in the Early Church as well as in the Middle Ages. Ephrem the Syrian, St Zeno of Verona, Augustine and Bernard of Clairvaux have all articulated points of view that confirm this. ${ }^{6}$ The idea was also popularized by medieval hymns such as the Gaude Virgo, which begins with the precise words

\footnotetext{
${ }^{4}$ See Alexander RoBERTs (transl.), The Ante-Nicene Fathers: The Writings of the Fathers Down to A.D. 325, Series I and II, Peabody, Mass., Hendrickson, 1971, VIII, p. 365.

${ }^{5}$ Lino Cignelli, Maria Nuova Eva nella Patristica greca, Assisi, Porziuncola, 1966, p. 133.

${ }^{6}$ In his seminal article on Filippo Lippi's Annunciation Leo Steinberg says that "In the Eastern Church, the conceptio per aurem fantasy never flourished ..." Leo STEINBERG, "'How Shall This Be?' Reflections on Filippo Lippi's Annunciation in London, Part I," Artibus et Historiae 16 (1987,) p. 28. To me it seems that there was no important difference between East and West on this issue.
} 
Gaude Virgo, mater Christi, quae per aurem concepisti (Rejoice, o virgin, mother of Christ, Who conceived through the ear). ${ }^{7}$

The choice of the ear as an alternative orifice was a natural one, since the child that she bore was the Son of God and hence the Incarnated logos -the Word of God. Each orifice has its function; while the genital opening is used for reproduction, the ear is for listening. But Mary, unlike other women, became pregnant by just listening to the Word of God. The Word of God entered her ear, and from there it went down into her womb, making her pregnant without taking her virginity. At this point the Fathers of the Church were quite explicit. Theodotus of Ancyra claimed that "Mary ... conceived the living God through the ear, for the ear is the natural entrance of words," her virginity, maintaining the seal of her integrity."

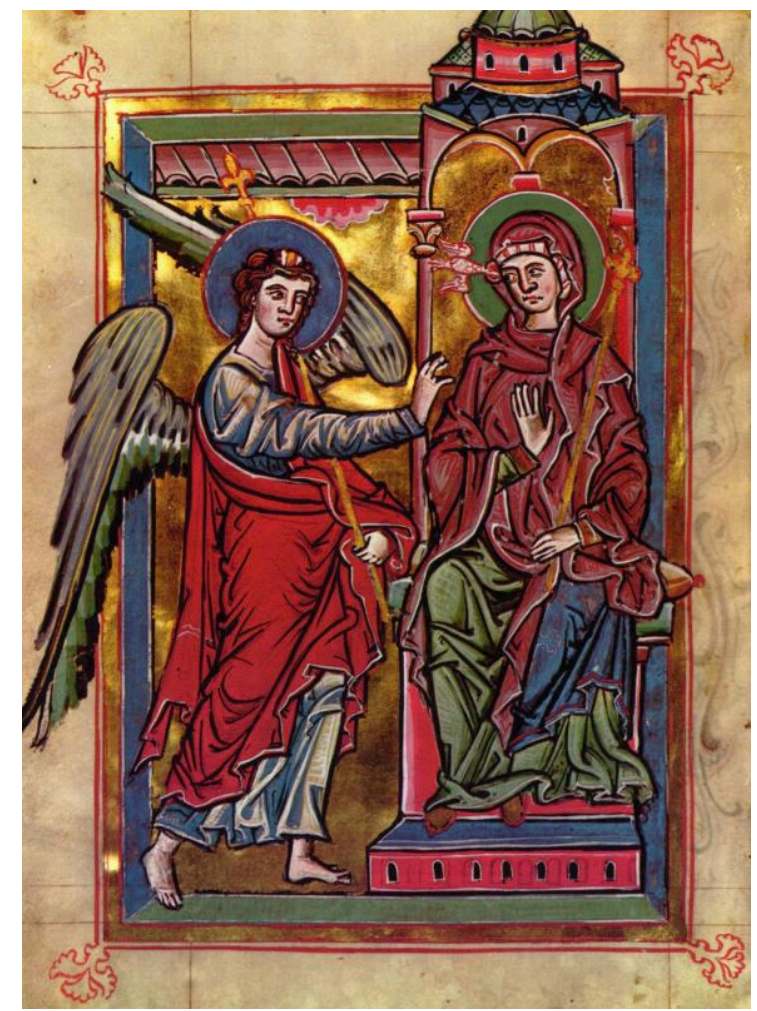

Fig. 3. Annunciation. Illustration by a master from the Braunschweig-Magdeburg school, now in the Österreichische Nationalbibliothek

In art, the Word of God, the Holy Ghost, is usually visualized by a dove. A number of Medieval and Renaissance book illuminations, panels and frescoes exist that show Mary literally with an ear that protrudes toward the dove as it arrives from overhead (Fig. 3). Her ear is transformed into a kind of funnel that permits the dove/Word of God to physically penetrate her body. In addition to this book illumination from Braunschweig, now in the Austrian National Library, numerous other examples can be mentioned: From Catalan art a fresco originally from the

\footnotetext{
${ }^{7}$ Yrjö HIRN, The Sacred Shrine: A Study of the Poetry and the Art of the Catholic Church, Boston 1957, p. 297.

${ }^{8}$ Cignelli, Op. cit., p. 194.

${ }^{9}$ Cignelli, Op. cit., p. 119.
} 
church San Pedro de Sorpe, now in the Museo de Arte Cataluña; a 13th-century statue in Trausnitz in Landshut, Germany; and, finally, also from Germany, a tympanum relief above the entrance to Mary's Chapel in Würzburg Cathedral (Fig. 4). In this final example, the angel arrives from the left with a banner in his hand, while the Virgin is seen on the right, kneeling, with a book in her hands. The dove is not immediately noticeable, as attention is instead drawn to the upper part of the painting, where a majestic Godfather sits on his throne inside an almond-shaped halo. The Father faces the front with a pipe stretching from his mouth, almost like an instrument, pointing towards the Virgin Mary. Close observation shows the Dove of the Holy Ghost emerging from the pipe as it reaches the Virgin's ear.

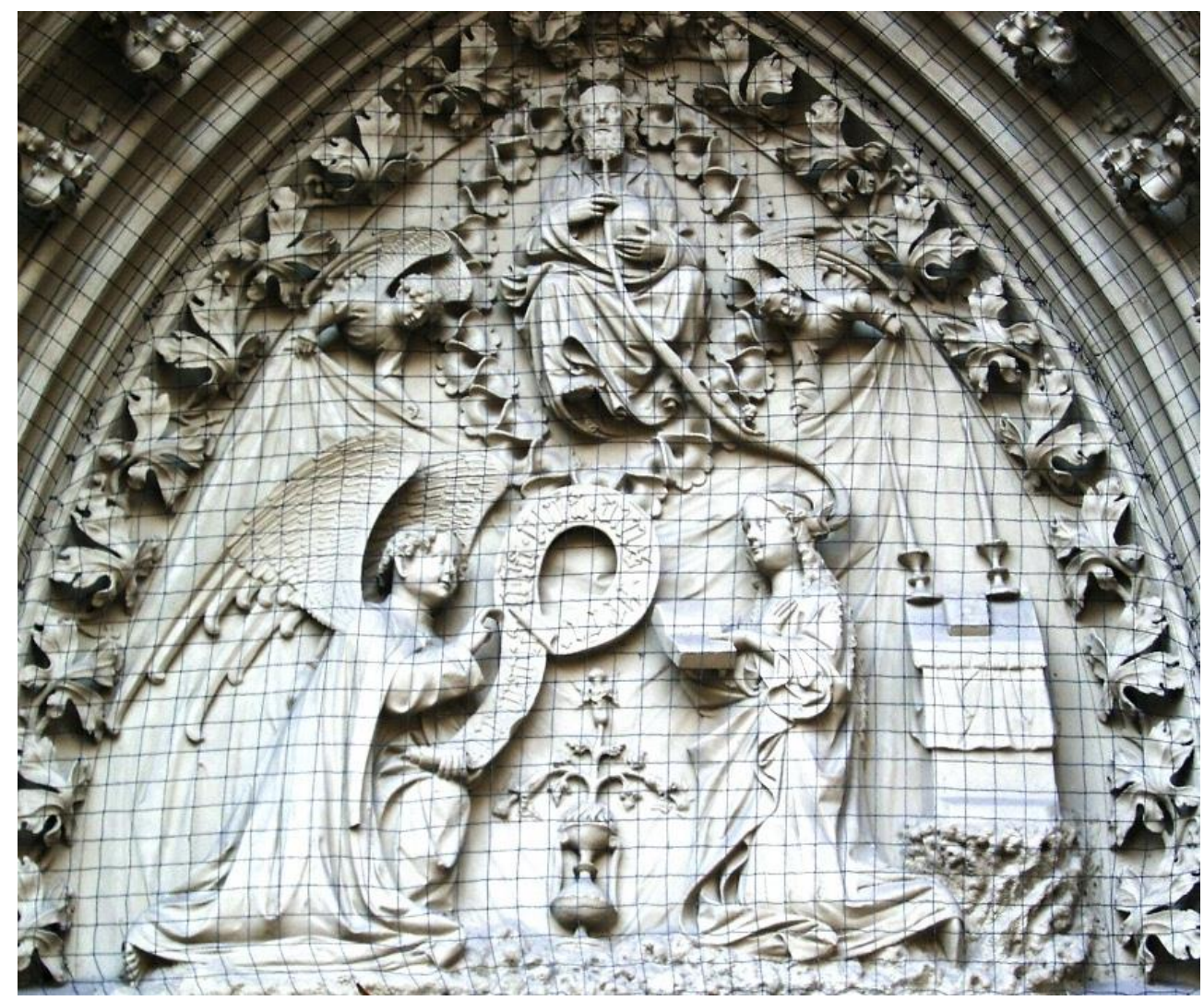

Fig. 4. Annunciation. Tympanum relief above the entrance to Mary's Chapel in Würzburg Cathedral

Similar examples can also be found in Dutch art. ${ }^{10}$

According to the Gospel of John, the Word is God (1:1). But in the same Gospel God also says that he is "the light of the world" (8:12). In representations of Christ in Majesty the Almighty is often seen with an open book in his left hand that displays the words Ego sum lux ("I am the light"). Like the above-mentioned Annunciations from various parts of Europe, Gentile's Vatican panel intends to demonstrate Mary's intactness as Semper virgo (Ever Virgin), but instead of revealing God as logos the picture displays him as lux. ${ }^{11}$

\footnotetext{
${ }^{10}$ Shirley Neilsen Blum, "Hans Memling's Annunciation with Angelic Attendants, Metropolitan Museum Journal, Vol. 27 (1992), pp. 49-50.

${ }^{11}$ The use of metaphors in art to represent Mary's virginity is also a theme in my book The Virginity of the Virgin. A Study in Marian Iconography, Rome, Scienze e lettere, 2012.
} 
Not only the Bible, but also Medieval treatises, testify that God is light. This is confirmed in Pierre Bersuire's (c. 1290-1362) Reductorium Morale. God himself must be light, Bersuire claims, since light is fire, which is the noblest of all elements. As evidence he referred to the fact that fire "lurks secretly in all things, as is evident when two bodies are struck together, for then the fire breaks out, though it was not at all believed to be hidden there..." ${ }^{\prime 2}$ I quote this from Millard Meiss, whose seminal work on the symbolism of light in Dutch 15th-century masters is essential when it comes to understanding use of light metaphors in art of this period. According to Meiss, Medieval artists derived their inspiration from ancient sources that were preserved and popularized by theologians of the Scholastic period. One such example is a text previously attributed to St Bernard of Clairvaux, ${ }^{13}$ which states: "just as the brilliance of the sun fills and penetrates a glass window without damaging it, and pierces its solid form with imperceptible subtlety, neither hurting it when entering nor destroying it when emerging: thus the word of God, the splendor of the Father, entered the virgin chamber and then came forth from the closed womb." ${ }^{14}$ From this, Medieval authorities drew the conclusion that Mary could not only conceive without damaging her hymen; she even gave birth without so much as a scratch on her vulva.

The topos, which was popularized through the hymn Dies est laetitiae, wherein one of the stanzas begins with ut vitrum non laeditur (as glass is not harmed), ${ }^{15}$ is of Early Medieval or, perhaps, even Late Antique origin. There is some evidence that it was known in Christian parishes in the Mediterranean region in Late Antiquity. The first documented example is a sermon from the fifth and sixth centuries that was (wrongly) attributed to the church father Augustine. A sermon beginning with the words Sanctus hic cum declineat contains formulations regarding the rays of the sun that are very similar to those attributed to Bernard of Clairvaux. ${ }^{16}$

Later, different variants of the theme can be found in the poetry of the scuola siciliana (Jacopo da Lentini), in the typological Pictor in Carmine, ${ }^{17}$ as well as the Mariale, which forms the last parts of the Sermones of Jacopo of Voragine - author of the Golden Legend. It even appeared in Scandinavia, more precisely in the writings of St Bridget of Sweden. Bridget, who saw the Mother of Christ in her visions during a pilgrimage trip to the Holy Land, compared the body of the Virgin to

${ }^{12}$ Millard MEISS, “ Light as Form and Symbol in Some Fifteenth-Century Paintings," The Art Bulletin, Vol. 27, No. 3. (Sep., 1945), p. 176.

${ }^{13}$ Saint Bernard has been mentioned here as the alleged source of the late medieval knowledge of the Sicut sol vitrum non laedit topos. More recent research has cast doubt on this claim, referring to the fact that the phrase "Sicut splendor solis" - the opening words of the text cited by Meiss- cannot actually be found in his corpus. Meiss appears to have relied on inadequate secondary sources instead of consulting the original text himself. See Andrew BREEZE, "The Blessed Virgin and the Sunbeam through Glass," Celtica 23 (1999), p. 24.

${ }^{14}$ MeIss, Op. cit., p. 176. My Italics, LH.

${ }^{15}$ MeISS, Op. cit., p. 179.

${ }^{16}$ BREEZE, Op. cit., p. 23.

${ }^{17}$ For typology, see for example Karl-August WIRTH, Pictor in Carmine. Ein typologisches Handbuch aus der Zeit um 1200, Berlin, Gebr. Mann, 2006, p. 113. 
translucent crystal. "The sun", she said, "does not damage the glass by entering it, nor was the Virgin's virginity lost when I [Jesus] took my human nature.",18

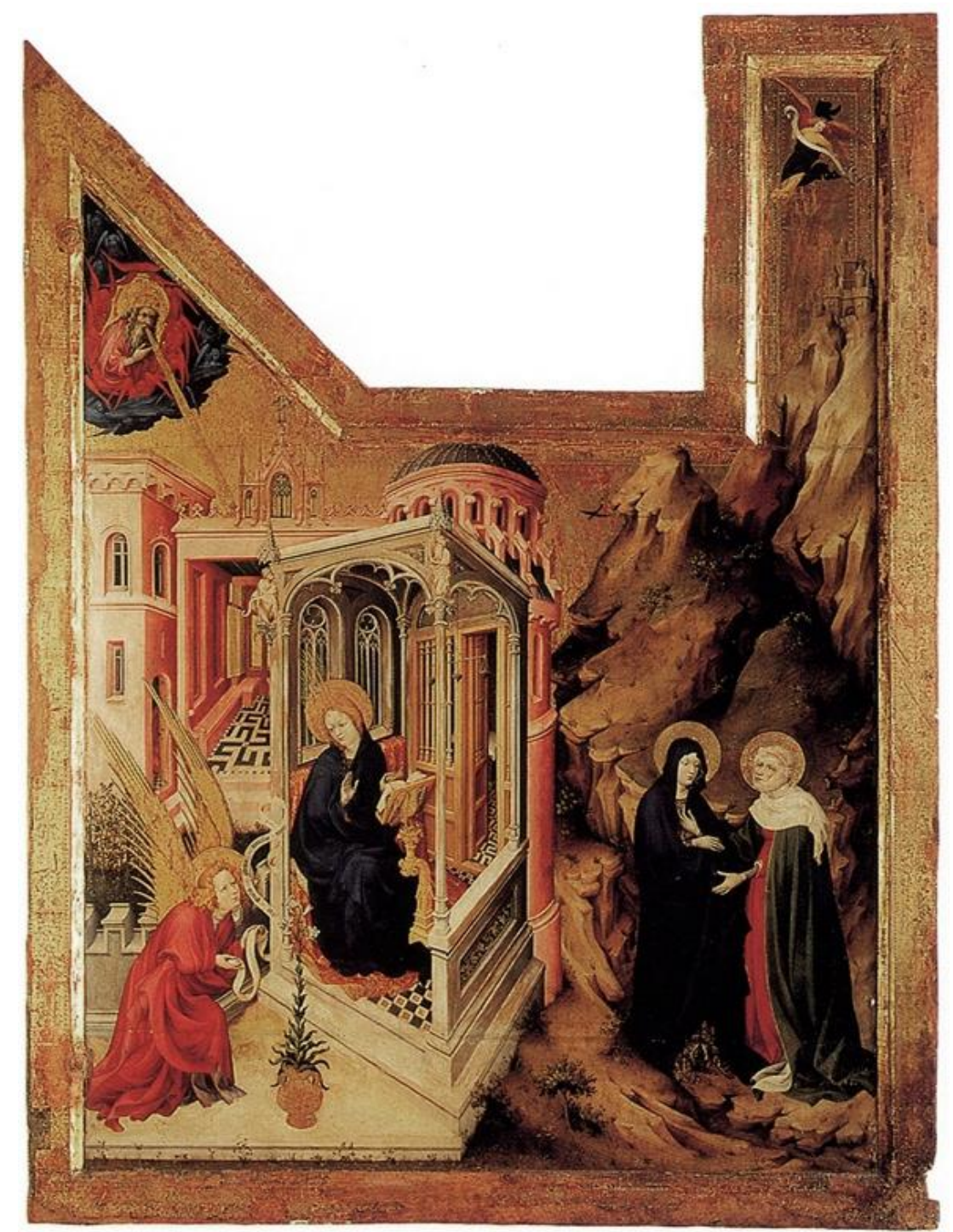

Fig. 5. Melchior Broederlam, Annunciation, Musée des Beaux-Arts of Dijon

From the time of St Bridget (who died in 1373) onwards, a large number of depictions of the Annunciation exist that in one way or another elaborate the theme of light penetrating the glass that we also find in Gentile's work. Due to Meiss's studies, most attention has been dedicated to the Dutch masters of this period. Among the works most frequently cited in the literature are Broederlam's Dijon Annunciation; an Annunciation in the Tres riches heures by Duc de Berry; two paintings by Jan van Eyck (the St Bavo church in Ghent and a painting in the National Gallery, Washington DC); as well as in a work by the Master of Flémalle (The Mérode collection).

In Meiss's article there is no in-depth discussion of the relationship between Flemish and Italian art with regard to this iconography. Yet, from his discussion of

${ }^{18}$ BRIDGET OF Sweden, Saint. The Revelations of St. Birgitta of Sweden (eds. D. Searby and B. Morris), Oxford U. Pr., 2006 I, [1], p. 53. 
the symbolic meaning of the water carafe in Filippo Lippi's Annunciation in San Lorenzo, which, according to him "seems to be another instance of Flemish influence,"19 one must assume that he thought that the iconography of light penetrating the glass as a symbol of virginal intactness was of Flemish origin. ${ }^{20}$

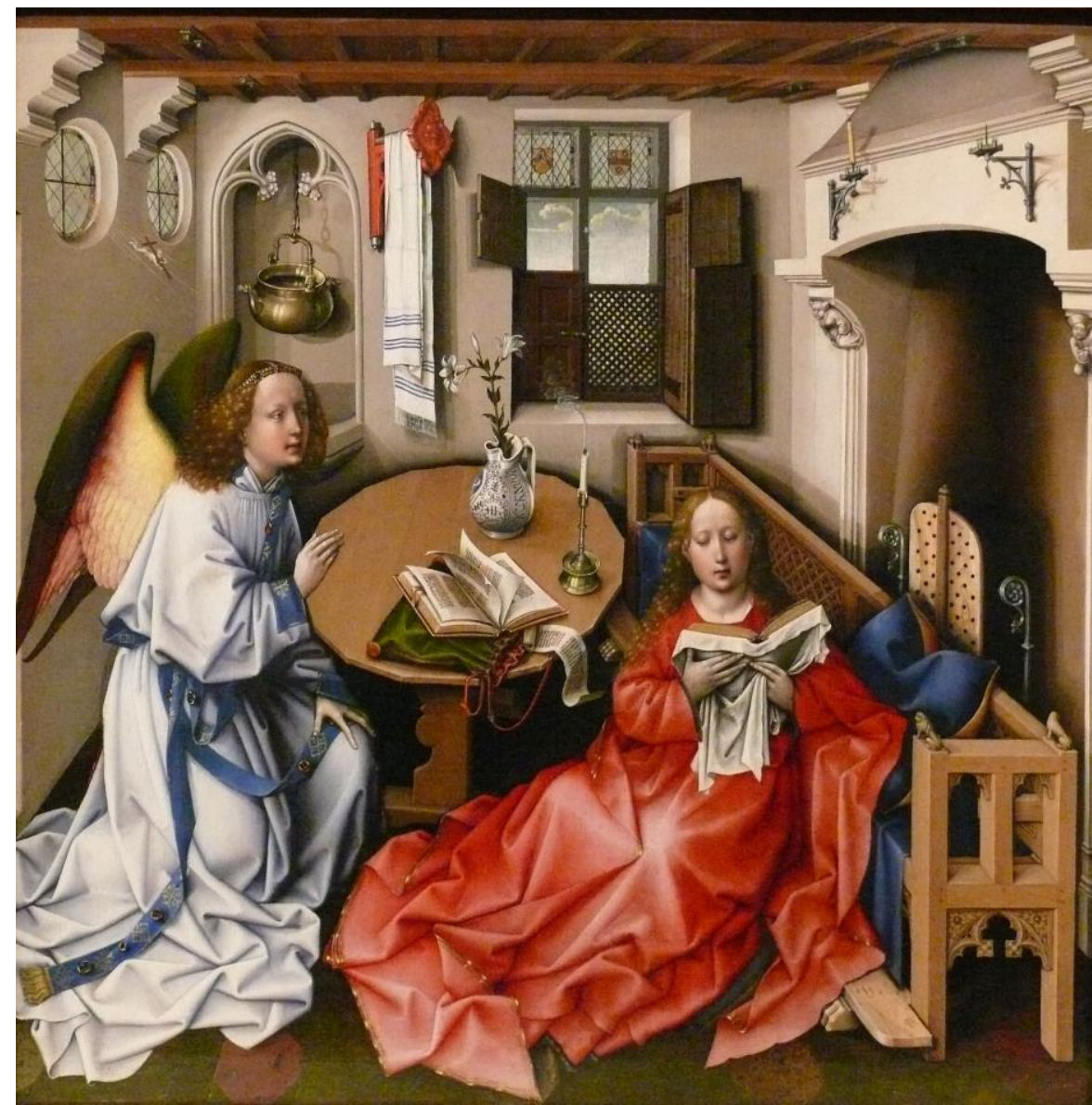

Fig. 6. Robert Campin, Mérode Altarpiece, Metropolitan Museum of Art in New York

This can also be gathered from his analysis of a number of Annunciations by Dutch masters of the late 14th and early 15 th centuries, which led him to conclude that the earliest instance of this iconography had to be Melchior Broederlam's Annunciation, in the Musée des Beaux-Arts of Dijon, which was painted between 1394 and 1399 (Fig. 5). ${ }^{21}$ In Broederlam's painting the Virgin sits on a bench with an open book in front of her as she turns her head to the right toward the angel, who arrives with his message written on a scroll. The Virgin sits in an opened-up Gothic building. In the top left corner we see God the Father towards the golden sky. From his mouth issue rays of light directed towards the head of the Virgin. As the rays approach, they penetrate one of the two large arched windows located behind Mary's back.

\footnotetext{
${ }^{19}$ MeISS, Op. cit., p. 179, n. 27.

${ }^{20}$ Speaking about the Annunciation by Filippo Lippi, Jeffrey RUDA says that there are basically two groups of images that use the glass metaphor, those focusing on glass windows (vitreae) and those focusing on glass objects (vitrum). Jeffrey RUDA, "Flemish Painting and the Early Renaissance in Florence: Questions of Influence," Zeitschrift für Kunstgeschichte, vol. 47 (1984), p. 229.
}

${ }^{21}$ MeIss, Op. cit., p. 178. 
The theme of the rays of light sent out from God that penetrate a glass window as they enter the room of the Virgin recurs in a number of early 15th-century Flemish paintings. Possibly the first important artist to pick up this thread was Robert Campin (earlier known as the Master of Flémalle). Like Broederlam's work, the central panel of his so-called Mérode Altarpiece (currently at the Metropolitan Museum of Art in New York), represents the Annunciation (Fig. 6). Usually assumed to have been painted in the $1420 \mathrm{~s},{ }^{22}$ it shows the Virgin in an interior filled with symbolically charged objects, like the lilies in a vase on the table, a just-extinguished candle, and a laver for washing (probably a symbol of purity) in a niche in the background. But most important for us is the top left of the picture, where we see two oculus windows (circular windows, not Gothic pointed arches as in Broederlam). Despite the shape of the window, the absence of the figure of the Almighty, and of the dove in Campin's case, there is one important similarity between these two paintings: The window is penetrated by a number of light rays directed towards the Virgin. In Campin's painting the rays carry a thumbnail-sized Christ child, fully shaped, with a cross on his shoulders, apparently flying along with the rays toward his future mother.

A quite different setting is found in Jan van Eyck's (about 10 years younger) Annunciation (1434-1436) in the National Gallery of Art, Washington DC (Fig. 7); a panel painting transferred to canvas that was originally probably the left wing of a triptych. ${ }^{23}$ Here, too, the scene is filled with significant details, but unlike Campin's Annunciation the Virgin is not in her private room, but standing upright in the nave of a Gothic church. There is no oculus, but again our attention is drawn toward the top left, where rays of light penetrate one of the clerestory windows. In the middle of the rays, which constitute a direct line between the window and the head of the Virgin, is the Holy Ghost in the shape of a dove.

Among the masterpieces that adopt the ut vitrum metaphor can be mentioned Rogier van der Weyden's Annunciation in Alte Pinakothek, Munich, Germany, as well as an Annunciation work by a master of Dutch origin active in Southern France: Barthélemy d'Eyck, possibly a younger relative of Jan van Eyck. ${ }^{24}$ Like Campin's painting, Barthélemy's Aix Annunciation (1443-1445) is the central part of a triptych that was dismembered and divided between museums in Rotterdam, Amsterdam and the Église de la Madeleine in Aix-en-Provence (central part with the Annunciation). Like in Jan van Eyck's picture the Virgin is located in a church interior, but the important detail with the window is more like that of Campin. Again, the top left of the picture is dominated by rays issuing from the Almighty that penetrate a rose window on their way to the Virgin.

${ }^{22}$ Meyer ScHAPIRO, "Muscipula Diaboli, The Symbolism of the Mérode Altarpiece," The Art Bulletin,

Vol. 27, No. 3 (Sep., 1945), p. 184.

${ }^{23}$ Melanie GIFFORD, "Van Eyck's Washington Annunciation: Technical Evidence for Iconographic Development," The Art Bulletin, Vol. 81, No. 1 (Mar., 1999), p. 108, n. 1.

${ }^{24}$ For a study of Barthélemy d'Eyck, see Yoshiaki NisHINO, "Le Triptyque de l'Annonciation d'Aix et son Programme iconographique," Artibus et Historiae, Vol. 20, No. 39 (1999), pp. 55-74. 


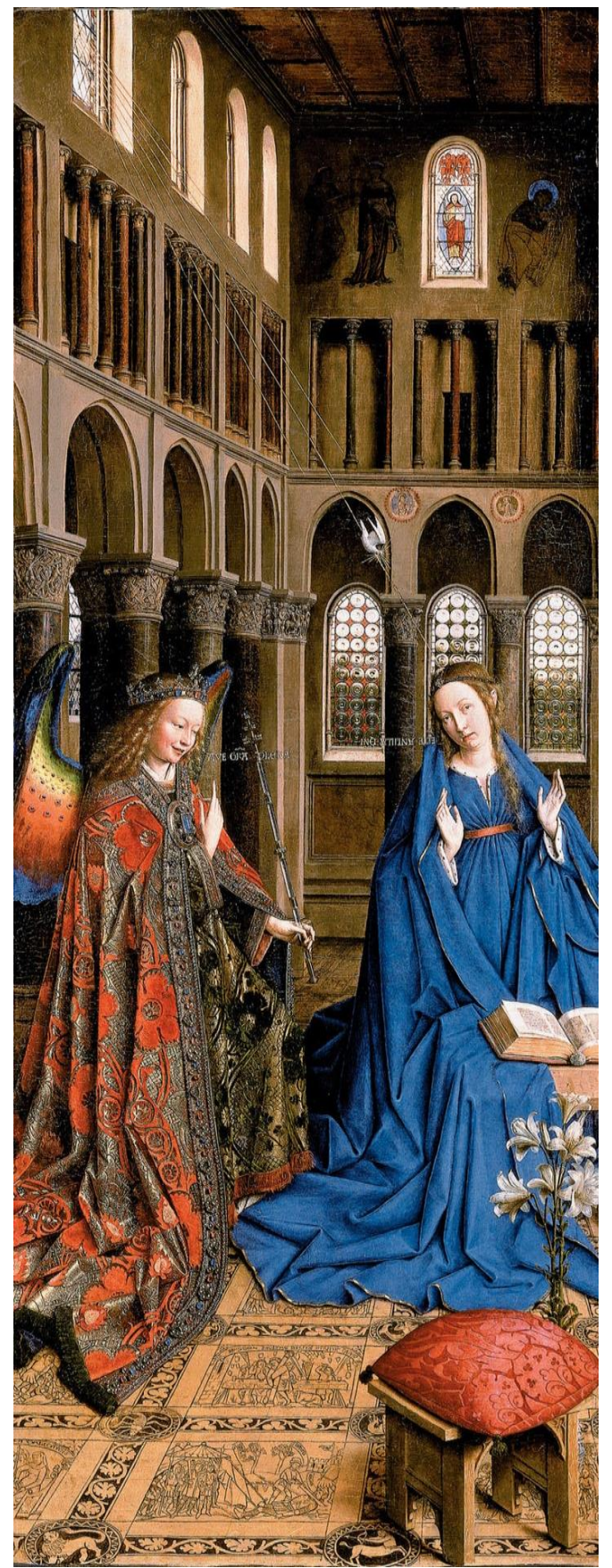

Fig. 7. Jan van Eyck, Annunciation, National Gallery of Art, Washington DC

According to Meiss, Broederlam's painting was the first in a series of, for the most part, Flemish Annunciations that adopted the ut vitrum metaphor as an image of Mary's virginity. He claims this despite the fact that, as he admits, even earlier representations of the Annunciation exist that, in a similar way, show rays of light that somehow pierce the wall as they enter Mary's room. Meiss here referred to examples from French illuminated manuscripts (one in the Hours of Jeanne de Navarre (1342), another in the Breviaire de Belleville (before 1343)), ${ }^{25}$ as well as in Tuscan 14th-century painting. Of the two Tuscan examples, one was in the Vatican (Meiss did not specify exactly which painting he had in mind) while the other,

\footnotetext{
${ }^{25}$ Both reproduced in David M. RoBB, "The Iconography of the Annunciation in the Fourteenth and Fifteenth Centuries," The Art Bulletin, Vol. 18, No. 4 (Dec., 1936), p. 494.
} 
located in the church of Sto Spirito in Prato, must be a painting that is usually attributed to Jacopo di Cione, ${ }^{26}$ probably painted around 1375 (Fig. 8).

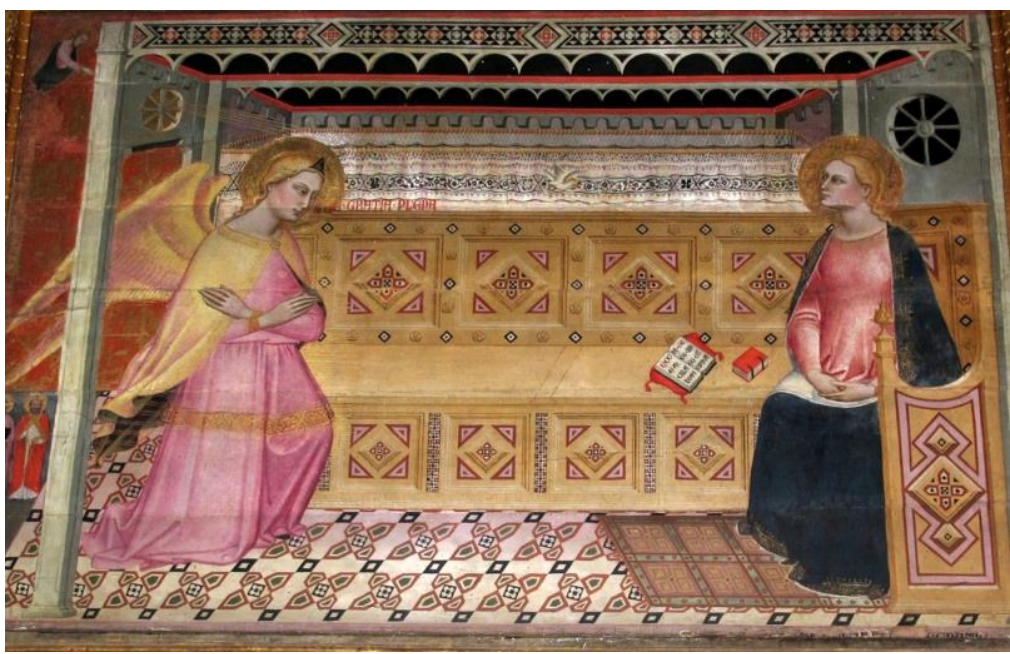

Fig. 8. Jacopo di Cione, Annunciation, Sto. Spirito, Prato.
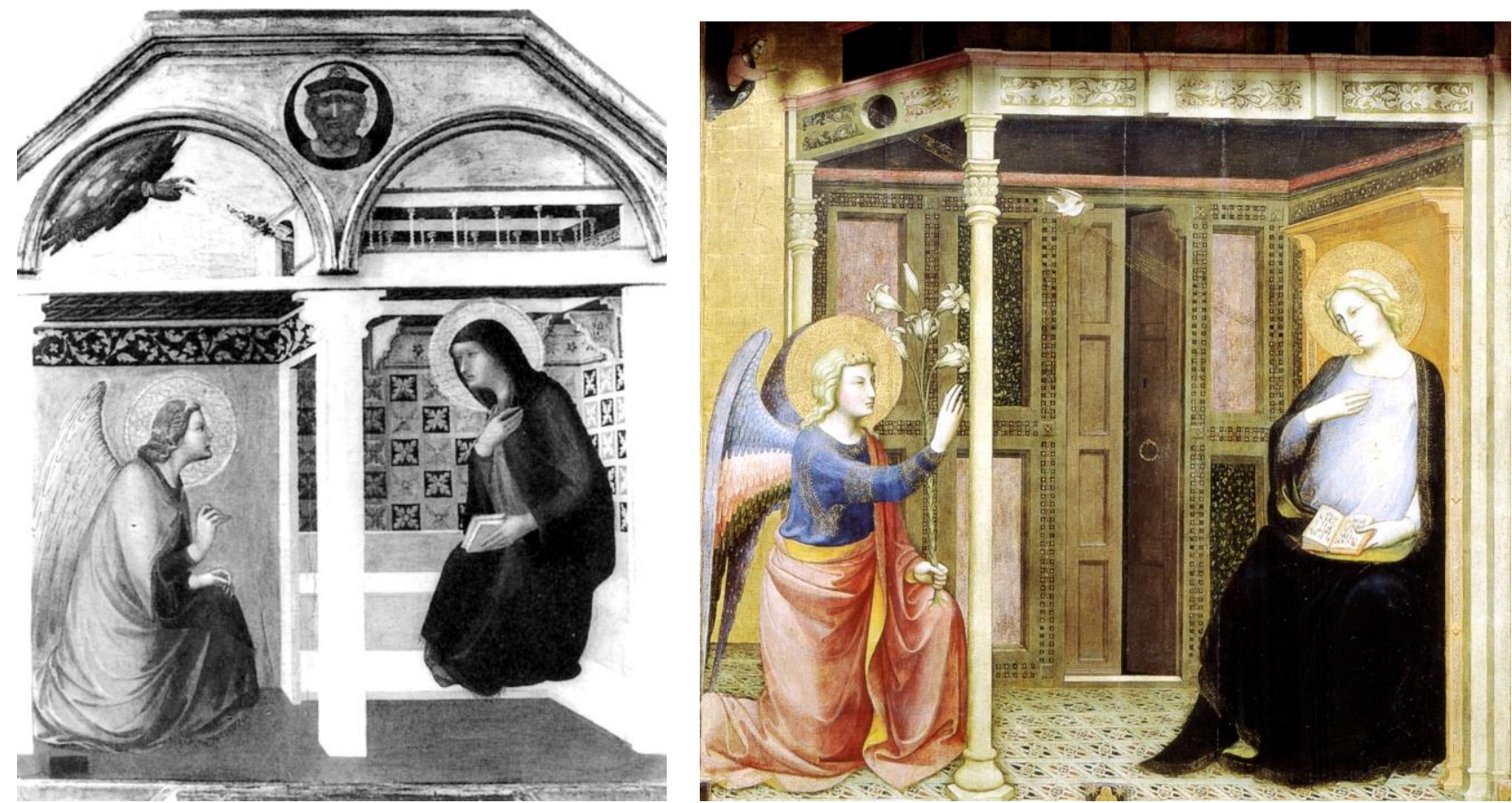

Fig. 9. Pietro Lorenzetti, Annunciation, Pieve polyptich, Arezzo.

Fig. 10. Master of the Straus Madonna, Annunciation, Galleria dell'Accademia, Florence.

Actually, Meiss could have gone even further back in history than this. An Annunciation that depicts rays issuing from (the hand of) God and entering the Virgin's room through a window opening can be found already in Pietro Lorenzetti's Pieve polyptych in Arezzo from 1320-1324 (Fig. 9). Much later, around 1390, the Master of the Straus Madonna made a similar painting, in which the rays from God penetrate a circular oculus window before entering the Virgin's room (Fig. 10).

\footnotetext{
${ }^{26}$ The attribution to Jacopo di Cione is uncertain. Offner limits himself to say that it is by an orcagnesque master. Richard OFFNER and Klara STEINWEG, A Critical and Historical Corpus of Florentine Painting, New York, Institute of Fine Arts, 1965, s. IV, vol. III . (Jacopo di Cione), p. 137, n. 2.
} 
The architectural setting of all these Annunciations, Flemish as well as French and Italian, is the so-called box interior, which allows the spectator a glimpse of the interior of the Virgin's house and the outside at the same time. Thus, the painter could safely place the Virgin inside and the Archangel outside without hiding any important elements from the eye of the beholder. True, there is one important difference between Broederlam's work and the earliest Italian examples. While the wall that separates the Angel from the Virgin in the paintings of Pietro Lorenzetti and the Master of Straus Madonna is seen from the outside (as if a spectator witnessing the original event was located close to the Angel), Broederlam shows it from the inside (as if the spectator was closer to the Virgin). Yet, already Jacopo di Cione's 1375 panel has a more "modern" setting, akin to that of the Flemish masters. As in Broederlam's painting, the wall is seen from the inside, and the window is an oculus similar to that in Robert Campin's work.

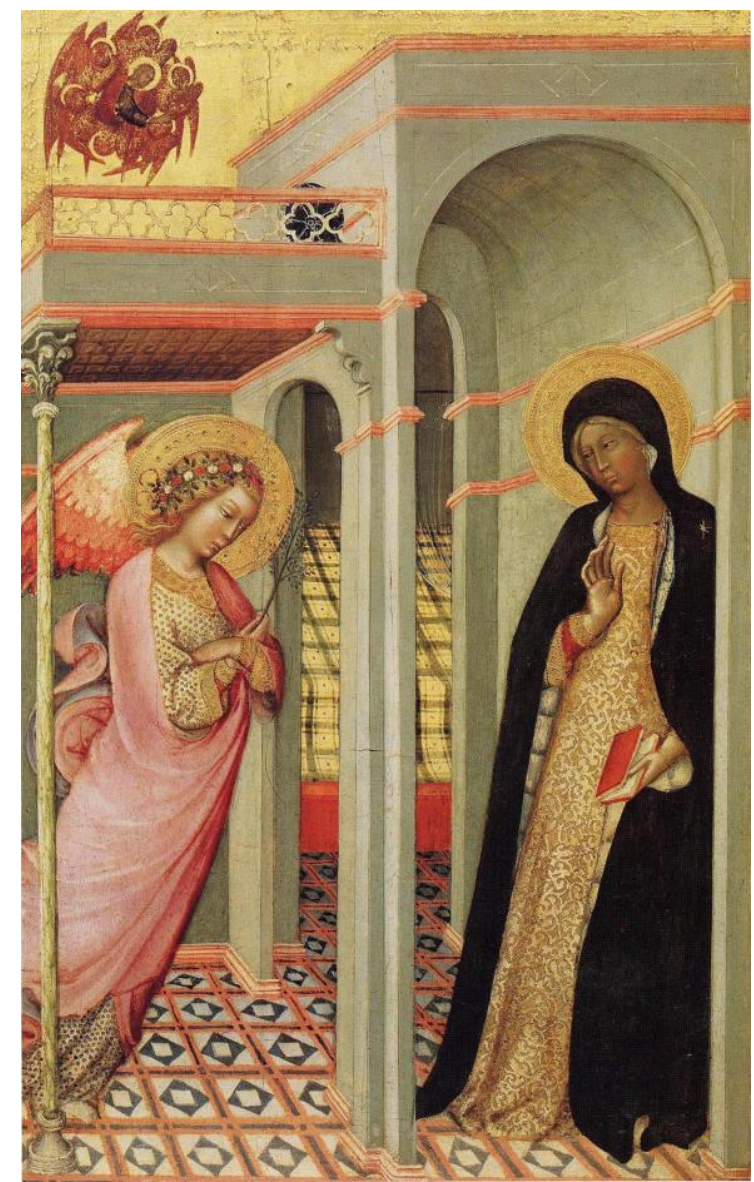

Fig. 11. Paolo di Giovanni Fei, Annunciation, Museo Amadeo Lia, La Spezia.

What all thlese Annunciations have in common is that light rays sent from God in one way or the other on their way toward the Virgin - who is made pregnant by this action - penetrate the wall of her house. The rays always enter through an opening that must be a window. In the earliest examples the glass is not always clearly seen, but in Paolo di Giovanni Fei's Annunciation in the Museo Amadeo Lia in La Spezia (Fig. 11), for instance, the Virgin's house is equipped with the same round oculus that we find in the Annunziata fresco, only it is seen from the outside.

I cannot therefore agree with Meiss, who concluded that "only a study of the original paintings would reveal whether or not there are small areas of glass in the 
windows of these or other representations of the Annunciation before Broederlam. In any event, the glass is prominent for the first time in Broederlam's work." ${ }^{, 27}$ It is very plausible that glass was intended from the very start in paintings such as that of Pietro Lorenzetti; in any event, Jacopo di Cione's Sto Spirito panel is proof that paintings of the Annunciation with a focus on the window and glass existed in Italian art at least 20 years before Broederlam made his painting. Italian masters evidently knew the ut vitrum metaphor, and its introduction in Christian iconography may very well have taken place in Italy - but exactly when?

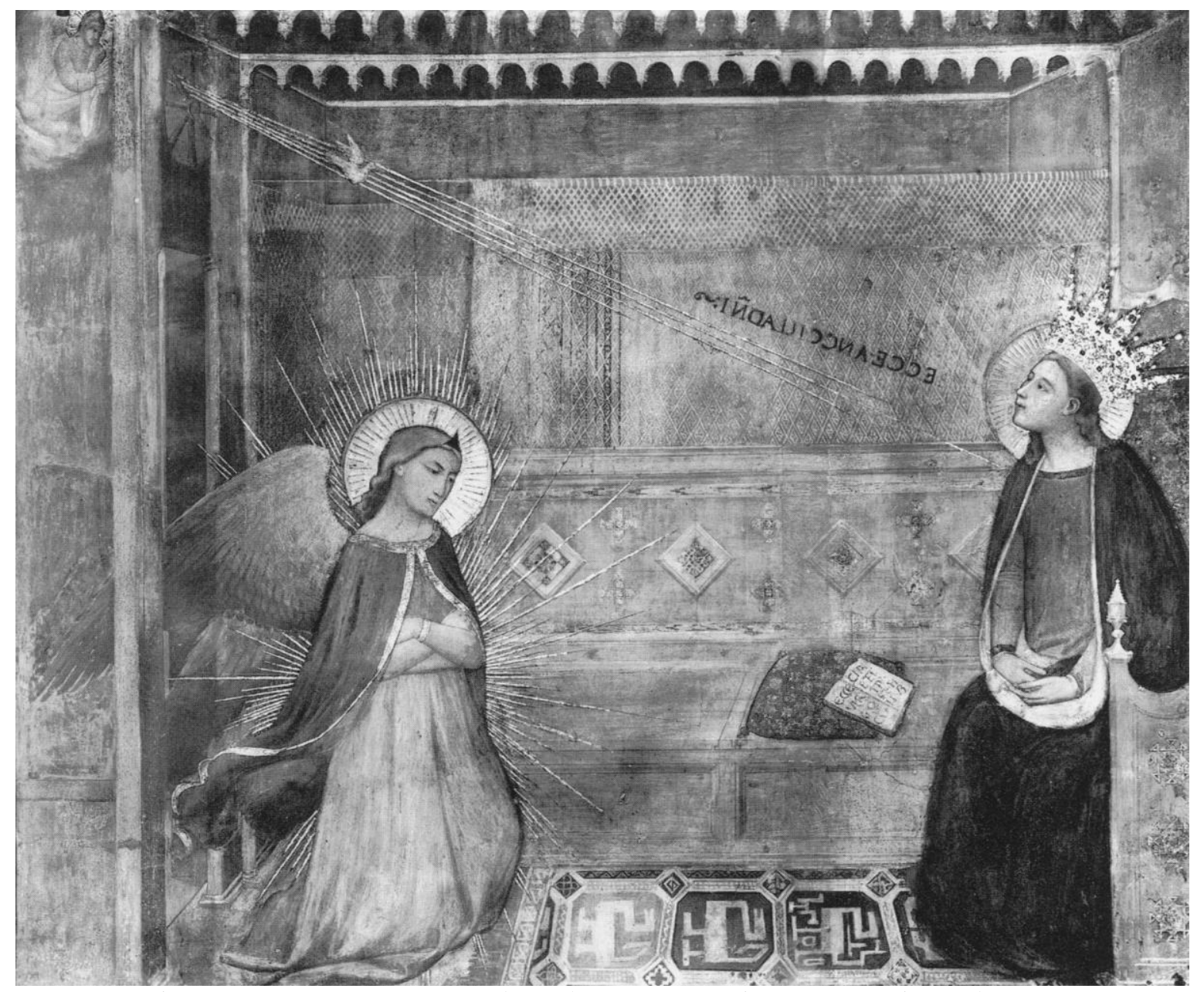

Fig. 12. Annunciation. Fresco by unknown master in Ss Annunziata, Florence

This question brings us back to Gentile, where rays from God directed toward the Virgin similarly penetrate the glass before they reach her body. As we shall see later, the use of the metaphor is even more explicit in Gentile's case, since the light and the shape of the rose window remain impressed on Mary's body, leaving no doubt that a window with glass is intended. True, Gentile's work was painted about 30 years after Broederlam's, but it is believed to be a replica of a famous fresco that can still be seen in the courtyard of the Servite church, Ss Annunziata, in Florence (Fig. 12) ${ }^{28}$ The reason why Gentile copied exactly this painting may relate to its status as a miraculous image. According to an ancient legend, the face of the Virgin in the

\footnotetext{
${ }^{27}$ MeIss, Op. cit., p. 178, n. 16.

${ }^{28}$ See, for instance, De MARCHI, Op. cit., p. 172 and n. 100.
} 
Annunziata fresco (which, of course, also represents the Annunciation), was painted by angels while the painter was asleep. ${ }^{29}$

Indeed, the two Annunciations (Gentile's and the one in Ss Annunziata) are very similar. In both, the Angel is seen arriving from the left through an open door as the Virgin sits on the right with her face turned slightly upward. The round windows through which the light of God shines are similar, only slightly more elaborated in Gentile's case. Most important as proof of a connection between the two paintings is, perhaps, the Turkish pile carpet on the floor, which is almost identical in the two paintings. ${ }^{30}$

We do not know the exact date of the Annunziata fresco. According to legend, the miraculous event that occurred when the painting was made took place in the year $1252 .^{31}$ It is difficult to say whether the original painting actually is from this period. What we do know is that it must have been repainted later, perhaps several times, since, as it appears today, it stylistically resembles works of a much later date. But how much later? Several suggestions have been made. According to Louise Bulman, the (re-) painting was executed by a master from the circle of Maso di Banco in the second quarter of the 14th century; ${ }^{32}$ Evelyn Sandberg Vavalà associated it with the school of Taddeo Gaddi (died 1366), ${ }^{33}$ while Miklos Boskovits attributed it to Jacopo di Cione (1325-1399). Eugenio Casalini, in his study on the Tesori of the Annunziata, dated it to roughly the mid-14th century. Analyzing the historical sources that document activity related to the fresco, Megan Holmes concluded that there "is suggestive, although by no means conclusive, evidence for proposing a date of 1340 for the painting of the fresco." 34

It seems that most studies fall between 1340 and 1370 when dating the fresco. Personally, I think this is too early. Although, as we have seen, there are clear analogies between the Annunziata fresco and Jacopo's Sto Spirito panel with regard to the interior of the Virgin's house and the position and shape of the window, stylistically it is much closer to Gentile da Fabriano. The carpet and a number of other details reveal that these two paintings are close, and the similarity in style is not because Gentile copied an old model. The Annunziata fresco is much more modern than Cione's work and cannot have been (re-) painted sometime between 1340 and 1360 .

\footnotetext{
${ }^{29}$ NN. Il Santuario della Santissima Annunziata di Firenze. Guida storico-illustrativa compilata da un religioso dei Servi di Maria, Florence, M. Ricci, 1876, pp. 16-17.

${ }^{30}$ Penny Howell JoLly, "Jan van Eyck's Italian Pilgrimage: A Miraculous Florentine Annunciation and the Ghent Altarpiece," Zeitschrift für Kunstgeschichte, 61 Bd., H. 3 (1998), p. 370 and n. 5.

${ }^{31}$ See note 26, above. For a discussion of the sources and the scholarly literature, see Maria Husab $\varnothing$ OEN, "The Origins of a Miraculous Image: Notes on the Annunciation Fresco in SS. Annunziata in Florence," Konsthistorisk tidskrift/Journal of Art History, n 80/1 (2011), pp. 1-22.

${ }^{32}$ Louisa M. Bulman, Artistic patronage at SS. Annunziata: 1440 - 1520, London: Courtauld Institute, 1971, ch. I, 10, cited through Megan HoLMES, "The Elusive Origins of the Cult of the Annunziata in Florence," in The Miraculous Image in the Late Middlea Ages and Renaissance (ed. by E. Thun $\varnothing$ and G. Wolf), Rome, L'Erma di Bretschneider, 2004, p. 108, n. 36.

${ }^{33}$ Evelyn Sandberg VAVALÀ, Studies in Florentine Churches, Florence, Olschki, 1959, p. 99.

${ }^{34}$ HOLMES, Op. cit., p. 110.
} 
However, what is important is that a late dating of the Annunziata fresco means that it was preceded by other paintings of the same subject that share some of its essential traits. We do not know what "the original" Annunziata of the 13th century actually looked like, but we know that the repainted version of the late 14th - early 15 th century resembles Jacopo di Cione's Sto Spirito panel with regard to the view of the interior and the shape and placing of the window. This, in turn, means that the $u t$ vitrum iconography was fully formulated in Florence toward 1370. Jacopo di Cione's activity as an independent painter started around 1366 (about 30 years before Broederlam made his Annunciation), and his Sto Spirito Annunciation is from about 1375.

The appearance of the same motif in Dutch art slightly before 1400, and its adoption by famous artists such as Robert Campin and Jan van Eyck, has led many to consider it as a typically Flemish trait. Discussing the art of Gentile da Fabriano, Andrea de Marchi concluded that the divine light that penetrates the window, which is also found in Pisanello's Annunciation in San Fermo, "is generally more common in Franco-Flemish painting than in Italian." 35 However, there is no evidence that the use of glass objects as symbols of virginal purity appeared in Flanders before Italy. Glass vases of the type found in Filippo Lippi's San Lorenzo Annunciation appeared in the late 1430s in Flemish and Florentine painting alike. ${ }^{36}$ As regards Jan van Eyck, Penny Howell Jolly sees a direct influence from Florentine art. ${ }^{37}$ The Florentine elements she observed in Jan's paintings include, first, two slim panels inserted between the Virgin and the Angel; second, the Virgin's reply to the Angel, ECCE ANCILLA DEI, written from the right to the left with the letters turned upside down; and, importantly, an emphasis on light symbolism. In the Ghent Altarpiece light falls on the wall in the secondary space behind Mary, while, as we have observed above, in the Washington Annunciation the flow of light is very similar to that found in Jan's Italian predecessors. ${ }^{38}$ Jolly's suggestion that Jan van Eyck travelled to Italy in the 1420s cannot, of course, account for the presence of such elements in Flemish art already in the 1390s, but it lends some credit to the theory that Flemish artists in the 1420 s and 30s were influenced by Florentine masters.

Of the two Annunciations by Van Eyck that we discuss here (he also made a third, now in the Thyssen Museum in Madrid), the one most similar to the Tuscan sources is the Washington painting. Yet this too differs from the Annunciations in the tradition from Jacopo di Cione to Gentile da Fabriano in one important respect. The Italian versions are characterized by their direct interpretation of the passage: sic Dei verbum, ..., virginum habitaculum adiit et inde clauso utero prodiit ("thus the word of God, ...., entered the virgin chamber and then came forth from the closed womb"). ${ }^{39}$ Although it is not specified exactly how the Holy Ghost enters the body of

\footnotetext{
35 "Questo dettaglio, il raggio divino che attraversa la finestra, è pure nell'Annunciazione di Pisanello in San Fermo a Verona, ma è in genere più diffuso nella pittura franco-fiamminga che in quella italiana...". De MARCHI, Op. cit., p. 172, n. 101.

${ }^{36}$ RUDA, Op. cit., p. 231.

${ }^{37}$ JOLLY, p. $374 \mathrm{ff}$.

${ }^{38}$ JOLLY, p. 381.

${ }^{39}$ Reproduced in Anselm SALZER, Die Sinnbilder und Beiworte Mariens in der deutschen Literatur und lateinischen Hymnenpoesie des Mittelalter mit Berürksichtigung der patristischen Literatur:
} 
Mary, the textual passage makes clear that the "holy chamber" and the place from which the incarnated God comes forth is her womb (utero).

To me, it seems that Gentile visualized exactly this. The rays in his Vatican Annunciation are clearly directed to a point right below Mary's breasts, thus illustrating the Gospel's words: ecce concipies in utero et paries filium et vocabis nomen eius Iesum ("And behold, you will conceive in your womb and bring forth a Son, and shall call His name Jesus") (Luke 1:31). Gentile was not the only painter active in Florence in the 1420s to have this idea. His contemporary, Bicci di Lorenzo (1373-1452), made an Annunciation for the church of San Nicolao in Buggiano near Pistoia that is very similar to Gentile's Vatican panel, except that God (with the semblance of the Son) appears in the window, rather than outside. But the window is still the circular oculus, and the rays are directed towards the Virgin's breasts where, it seems, they form a round shape of light. According to Jolly, the same detail, with light impressed on the Virgin's breasts, can be seen in Fra Angelico's Prado Annunciation. ${ }^{40}$

Most of these works of art have been restored during the years, and it is often difficult to discern spots of light were they may exist. However, it is important to emphasize that this discussion has two aspects. One is the round or polylobe shape impressed on Mary's breast or stomach in some (perhaps only a few) paintings; the other is the direction of light from God, which, in Tuscan works of the type that we discuss here, almost invariably hits Mary's body on a point well below her throat. This obviously goes for the mentioned works in which the shape of light is seen on her body (Gentile da Fabriano, Bicci di Lorenzo, Fra Angelico), but it is also true of other works by Florentine painters, such as Jacopo di Cione and the master behind the Annunziata fresco. This contrasts with works by French and Dutch masters of the same period. In the paintings we have studied by Jan van Eyck, Roger van der Weyden, and Barthélemy d'Eyck (and many more French and Flemish works could be mentioned here), the divine light is usually directed towards the top of the Virgin's head. In Van Eyck's Washington painting the divine ray of light made in gold clearly falls on Mary's head, and in the Ghent altarpiece the Dove of the Holy Ghost seems to be suspended motionless in the air about an inch above her head.

It has been suggested that Flemish art adhered to the ancient tradition that I outlined in the beginning, with the words of God in the shape of a dove entering into Mary's body through the ear. ${ }^{41}$ However, the dove is not always present and, in my view, the rays in the paintings we discuss here are not directed toward Mary's ear, but to the top of her head. This is in harmony with the instructions found in Dionysius of Fourna's early 18th century Hermeneia (The Painter's Manual). According to Dionysius, in the Annunciation the Holy Ghost is carried by rays toward the Virgin's head. ${ }^{42}$

eine literar-historische Studie, Linz, J. Feichtingers Erben, 1893, p. 74. Quoted through MEISS, Op. cit., p. 176.

${ }^{40}$ JOLLY, Op. cit., p. 381.

${ }^{41}$ Jonathan SAVILLE, The Medieval Erotic Alba: Structure as Meaning, New York and London, Columbia University Press, 1999, p. 82.

42 "Le saint Esprit en sort sur un rayon qui se dirige vers la tête de la Vierge." DiOnYsIUS PHURNENSIS (Dionysius of Fourna). Manuel d'iconographie chretienne grecque et latine 
One may discuss what relevance advice from a monk from Mount Athos specifically for icon painters in the Byzantine style can have for the understanding of Western European 15th-century art. However, the editor of the French translation, Adolphe Napoleon Didron, thought it was important. Indeed, in a note to precisely this passage he mentions, as an example, a panel in a small church in Aix en Provence. ${ }^{43}$ Could this be the central panel of Barthélemy d'Eyck's Annunciation that is kept in the Église de la Madeleine in that city?

The iconographical differences between Italian and Flemish art may indicate that they are based independently on textual sources, rather than being influenced reciprocally by each other. What is important is that the Tuscan version, where light is visibly impressed on Mary's breasts or on her womb, is a clear-cut demonstration that late-14th-century and early-15th-century painters adopted the light metaphor. This is more evident in Italian art than Flemish, and the emergence of this motif in Florence sometime between the 1360 s or 70 s suggests that the painterly equivalent of the $u t$ vitrum metaphor was invented precisely here.

\section{Bibliography}

BLuM, Shirley Neilsen, "Hans Memling's Annunciation with Angelic Attendants," Metropolitan Museum Journal, Vol. 27 (1992), pp. 43-58.

BREEZE, Andrew, "The Blessed Virgin and the Sunbeam through Glass", Celtica 23 (1999), pp. 19-29.

BRIDGET OF SwEDEN, Saint. The Revelations of St. Birgitta of Sweden (eds. D. Searby and B. Morris), Oxford U. Pr., 2006.

Bulman, Louisa M., Artistic patronage at SS. Annunziata: 1440 - 1520, London: Courtauld Institute, 1971.

CASAlini, Eugenio (editor), Tesori d'Arte dell'Annunziata di Firenze, Firenze, Alinari 1987.

Christiansen, Keith, Gentile da Fabriano, Ithaca, Cornell University Press, 1982, $193 \mathrm{p}$.

Cignelli, Lino, Maria Nuova Eva nella Patristica greca, Assisi, Porziuncola, 1966.

DIONYSIUS PHURNEnsis (Dionysius of Fourna). Manuel d'iconographie chretienne grecque et latine (Hermeneia) avec une introduction et des notes par m. Didron. Paris: Imprimerie Royale, 1845, 482 p.

DUNKERTON, Jill, Susan FOISTER, Dillian GORDON and Nicholas PENNY, Giotto to Dürer: Early Renaissance Painting in the National Gallery, New Haven and London, Yale Univ. Press, 1991, 408 p.

GIFFORD, Melanie, "Van Eyck's Washington Annunciation: Technical Evidence for Iconographic Development," The Art Bulletin, Vol. 81, No. 1 (Mar., 1999), pp. 108-116.

JOLLY, Penny Howell, "Jan van Eyck's Italian Pilgrimage: A Miraculous Florentine Annunciation and the Ghent Altarpiece," Zeitschrift für Kunstgeschichte, $61 \mathrm{Bd}$., H. 3 (1998), pp. 369-394.

(Hermeneia) avec une introduction et des notes par m. Didron. Paris: Imprimerie Royale, 1845, p. 155.

${ }^{43}$ Ibidem, n. 2. 
HIRN, Yrjö. The Sacred Shrine: A Study of the Poetry and the Art of the Catholic Church, Boston 1957.

Hodne, Lasse, The Virginity of the Virgin. A Study in Marian Iconography, Rome, Scienze e lettere, 2012, $138 \mathrm{p}$.

Holmes, Megan, "The Elusive Origins of the Cult of the Annunziata in Florence," in The Miraculous Image in the Late Middlea Ages and Renaissance (ed. by E. Thun $\varnothing$ and G. Wolf), Rome, L'Erma di Bretschneider, 2004, pp. 97-121.

MARCHI, Andrea de, Gentile da Fabriano. Un viaggio nella pittura italiana alla fine del gotico, Milan, Motta editore, 1992.

MEISS, Millard, "Light as Form and Symbol in Some Fifteenth-Century Paintings," The Art Bulletin, Vol. 27, No. 3. (Sep., 1945), pp. 175-181.

NISHINO, Yoshiaki, "Le Triptyque de l'Annonciation d'Aix et son Programme iconographique," Artibus et Historiae, Vol. 20, No. 39 (1999), pp. 55-74.

NN, Il Santuario della Santissima Annunziata di Firenze. Guida storico-illustrativa compilata da un religioso dei Servi di Maria, Florence, M. Ricci, 1876.

OEN, Maria Husabø, "The Origins of a Miraculous Image: Notes on the Annunciation Fresco in SS. Annunziata in Florence," Konsthistorisk tidskrift/Journal of Art History, $\mathrm{n}^{\mathrm{o}}$ 80/1 (2011), pp. 1-22.

OFFNER, Richard and Klara STEINWEG, A Critical and Historical Corpus of Florentine Painting, New York, Institute of Fine Arts, 1965, s. IV, vol. III . (Jacopo di Cione), $155 \mathrm{p}$.

ROBB, David M., "The Iconography of the Annunciation in the Fourteenth and Fifteenth Centuries," The Art Bulletin, Vol. 18, No. 4 (Dec., 1936), pp. 480-526.

ROBERTS, Alexander (transl.), The Ante-Nicene Fathers: The Writings of the Fathers Down to A.D. 325, Series I and II, Peabody, Mass., Hendrickson, 1971.

RUDA, Jeffrey, "Flemish Painting and the Early Renaissance in Florence: Questions of Influence," Zeitschrift für Kunstgeschichte, vol. 47 (1984), pp. 210-236.

SALZER, Anselm, Die Sinnbilder und Beiworte Mariens in der deutschen Literatur und lateinischen Hymnenpoesie des Mittelalter mit Berürksichtigung der patristischen Literatur: eine literar-historische Studie, Linz, J. Feichtingers Erben, 1893.

SAVILLE, Jonathan, The Medieval Erotic Alba: Structure as Meaning, New York and London, Columbia University Press, 1999, 364 p.

SCHAPIRO, Meyer, "Muscipula Diaboli, The Symbolism of the Mérode Altarpiece," The Art Bulletin, Vol. 27, No. 3 (Sep., 1945), pp. 182-187.

STEINBERG, Leo, “' 'How Shall This Be?' Reflections on Filippo Lippi's Annunciation in London, Part I," Artibus et Historiae 16 (1987) pp. 25-44.

VAVALÀ, Evelyn Sandberg, Studies in Florentine Churches, Florence, Olschki, 1959.

WIRTH, Karl-August, Pictor in Carmine. Ein typologisches Handbuch aus der Zeit um 1200, Berlin, Gebr. Mann, 2006. 